\title{
Shifting back to and away from girlhood: magic changes in age in children's fantasy novels by Diana Wynne Jones
}

\author{
Sanna Lehtonen \\ Department of Culture Studies, Tilburg University, The Netherlands
}

\begin{abstract}
The intersection of age and gender in children's stories is perhaps most evident in coming-of-age narratives in which aging, and the ways in which aging affects gender, are usually seen as natural, if complicated, processes. In regard to coming-of-age, magic changes in age in fantastic stories whether the result of a spell or a time-shift - are particularly interesting, because they disrupt the natural aging process and potentially offer critical perspectives on aged and gendered subjectivities. This paper examines age-shifting caused by fantastic time slips in two novels by Diana Wynne Jones, The Time of the Ghost (1981) and Hexwood (1993). The main concern of the paper is how the female protagonists' gendered and aged subjectivities are constructed in the texts, with a particular focus on the representations of girlhood. Gender and age are examined both as embodied and performed by examining the ways in which the shifts back to and away from girlhood affect the protagonists' subjective agency and their experiences of their gendered bodies at different ages.
\end{abstract}

Keywords: femininity, age, subjectivity, fantastic transformations, age-shifting, Diana Wynne Jones

\section{Slipping in time, drifting through identities: age-shifting and subjectivity}

Stories about magic age-shifting, whether describing regained youth or premature adulthood or old age, abound in mythologies, folktales and fiction. Fountains of youth and visits to fairyland are among the traditional motifs, but age-shifting has remained popular in contemporary children's fiction, particularly in the form of time slips to one's past or future, (pseudo)scientific techniques that can stop cells from aging, or body swapping experiences. The popularity of the motif is undoubtedly explained by the fact that aging concerns everyone; magic age-shifting is a fascinating narrative device because it addresses both material aging and social aspects of age. In children's fiction, age-shifting often occurs as a temporary experiment with subjectivity. This usually involves learning by trying to walk in someone else's shoes, be it another person of a different age (as in body swapping) or one's own younger or older self. Age-shifting can be utilised to critically explore embodied subjectivity: how does a subject's material body affect her sense of identity, agency and the ways in which other people regard her in social interaction? ${ }^{1}$ 
Age-shifters are, in a sense, in disguise and therefore their transformation is firmly connected to ideas of identity and performativity - the question is whether age-shifters are able to perform the new social, aged and gendered identity associated with their transformed material body. If the age-shifter is not able to 'act her age', the performance can become comic; abrupt age-shifting highlights the challenges involved in trying to behave like someone else without the time to practice the performance ${ }^{2}$.

Diana Wynne Jones is a fantasist who has frequently employed magic age-shifting in novels that thematise identity construction ${ }^{3}$. As Deborah Kaplan (2010) writes, Jones's oeuvre involves 'a continuing theme of disguised age and age disruption ... protagonists who age in more than one direction, protagonists who don't know their own age, [and] protagonists in disguise as characters older or younger than themselves' (p.197). The performativity of age is addressed in Jones's texts where characters magically turn older or younger and have to adapt to their new bodies as well as they can. Whereas Judith Butler (1996, pp.111-112) emphasises that gender is performative in the sense that it is produced in discourse, and enforced through repetition (i.e., it is not a 'costume/role' that a person can easily change at will) some of Jones's characters are able to adapt their behaviour according to their 'costume'. For instance, after transforming from a young girl into a 90-year-old woman Sophie in Howl's Moving Castle (1986) chooses to behave stereotypically like a grumpy hag and thus accommodates her behaviour to the expectations that her new bodily identity creates. Because readers are aware of her disguise, Sophie's performance becomes parodic and highlights the social expectations associated with women of different ages.

However, elsewhere Jones's characters are not conscious about their identity performance but are acting their aged and gendered identities habitually and unconsciously. The depiction of unconscious performance of identity is possible in texts where characters are unaware that they have undergone bodily changes because of memory loss at the moment of transformation. The memory loss causes a disruption in the character's identity narrative and functions as a narrative device to address the construction of subjectivity. Maturation processes that involve false memories and shifts in time occur in several novels by Jones, including The Time of the Ghost (1981), Archer's Goon (1984), Fire and Hemlock (1985) and Hexwood (1993). In these novels the continuity between the protagonists' present and past selves is lost at the beginning but regained later with reconstructed memories of the past. The texts employ structural irony as a narrative strategy to expose conventional assumptions about gendered and aged subjectivities while characters believe they are being their 'true' selves, the moment that their disguise is revealed the behaviour of the deluded heroes is recontextualised. Since my interest is in the intersection of age and femininity, I will examine The Time of the Ghost and Hexwood, which depict patterns of female maturation. While Fire and Hemlock also does this, the protagonist does not experience magic age-shifting but merely realises that her memory has been partially lost; the text is thus structurally different from the other two novels. 
The Time of the Ghost and Hexwood can be defined as girls' coming-of-age stories that involve fantastic time slips as part of the process: the age-shifting of the female characters results from them slipping in time. As Linda Hall (2001, p.46) writes, post-war British time-slip narratives have been keen to explore identity in relation to continuity in time; personal and cultural inheritance and identities are based on the relationship between the past and the present. However, unlike many British time-slip stories, where cultural and national inheritance is addressed alongside characters' personal experiences of the past and the present (see Hall 2001; Cosslett 2002), in Jones's texts the protagonists visit their own pasts and the focus is on the construction of their subjectivity in relation to their personal identity narratives. The time slips in The Time of the Ghost and Hexwood involve a partial memory loss, which enables the juxtaposition of the female characters' pre-teen/teenage identities and their young adult identities, because they initially believe they are younger than they truly are. The time slips initially deconstruct the girls' subjectivities, as argued by Charles Butler (2006, p.68) and Margaret Rumbold (1997, pp.23-26), who both suggest that the play with time challenges the conventional notion of subjectivity as unique and continuous. However, I will argue further that the play with time and with subjectivity is represented as a problem to be solved. The scenes where the girls remember their 'true' identities are marked as key moments in terms of coming-of-age, and the mystery story structure in the narratives emphasises the ending where the characters have discovered not only what the true story was but effectively, their true identities.

I will examine aged and gendered subjectivity in Jones's novels by addressing three questions. First, how do the characters experience their bodies? Second, how do they view their present and past selves and whose versions and experiences of past and present are validated in the narrative, particularly at the moment when the characters regain their memory? In each novel, focalisation provides an access to the characters' experiences of their gendered bodies at different ages. The Time of the Ghost is focalised almost completely through Sally, the protagonist, whereas the narrative structure in Hexwood involves multiple focalisers and Vierran's, the female protagonist's maturation process is only one strand in the story. However, it is instructive to compare the protagonists' development because there are several parallels in the portrayal of girlhood and the maturation process. Finally, I will consider how the shifts back to and away from girlhood affect the protagonists' agency. While dealing with these questions, I will rely on poststructuralist feminist theories on aged and gendered subjectivity.

\section{Aged and gendered subjectivity: embodiment, discourse, narrativity}

Contemporary feminist theory approaches subjectivity as a formation based on three main aspects: embodiment, discourse and narrativity. As regards the first two aspects, subjectivity is based on a material, gendered and aged body, but social discourses regulate how material bodies are interpreted and what is appropriate, normal behaviour for a person of a certain gender and age. In their adaptations of Foucault's theorisation of body, Rosi Braidotti (2005) and Judith Butler (1999) emphasise the ways in which discourses regulate gendered subjects' bodies and behaviours (cf. Foucault 1979 on 'docile bodies'). For Braidotti (2005, p.26) 'discursive practices, imaginary identifications or ideological beliefs are tattooed on bodies and thus are constitutive of embodied subjectivities' - these practices, identifications and beliefs shape the notions of various ways of being a gendered subject. Butler (1999, 
p.199) emphasises a subject's active role in 'doing' identities and views gender as performatively constituted through the 'stylized repetition of acts'. Gender is performed by repeating behaviours associated with versions of femininity and masculinity in social discourses about gender. Through repetition, ways of doing gender become habitual, 'tattooed on bodies' and inscribed in what Mieke Bal (1999, pp.vii-viii) calls 'habitual memory': habits are learned, internalised modes of behaviour that are automatic and mostly unconscious, embedded in memory, even though originally enforced by discipline. Like gender, age is based on a material body but is also a discursive construction: as Margaret Cruikshank (2003, pp.173-174) notes, 'aging can be performed' because of a culturally determined idea that "'old" limits certain behaviour or style choices'. While Cruikshank refers to old age, discourses of different phases of life also limit the choices at other ages (for example, the appropriate behaviour for a woman of ten or fifty).

The third aspect of subjectivity, narrativity introduces continuity and coherence between the varying experiences of embodiment and the different ways of doing gender at different ages. Narrativity explains how a person whose material body is in constant change and whose social position thus also repeatedly shifts (because young/old, feminine/masculine bodies are interpreted and treated differently in society) can still understand herself as one and the same subject. Following Braidotti's notion of 'nomadic subjectivity' (pp.21-22), I maintain that subjectivity consists of a series of social locations that are negotiated in relation to other subjects and to discourses of gender and age. These locations are not disjointed but cohered by the experienced body and the sense of personal identity that is based on memory. Indeed, according to Adriana Cavarero (2000, pp.33-34) each individual desires her own story, which again forms her personal identity or, 'the narratable self'. For Cavarero, each person has a unique - but not necessarily unified - identity that lies in her story: a subject, both consciously and through the uncontrollable 'auto-narration' of memory, constructs her own narratable self. Although the idea of a narrative identity is hardly new - as Susan J. Brison (1999, p.41) remarks, the notion goes at least as far as John Locke - Cavarero's feminist input is to recognise the role of others in the construction of the personal narrative: because each individual is unable to tell one's story from birth to death, the 'necessary other' is needed to fill in the gaps (p.39). Moreover, in the process of shared storytelling social discourses of age and gender are incorporated in personal identity narratives or stories of gendered individuals going through different phases in life. Thus, subjectivity and personal identity are always intersubjectively constructed, or in other words, 'subjectivity is a socially mediated process' (Braidotti 2005, p.7).

In Jones's novels, each of the three aspects of subjectivity is deconstructed at some point in the narrative, yet all aspects are not deconstructed at the same time. At the beginning, the girls' experiences of embodiment are manipulated and their personal identity narratives are disrupted. Due to these manipulations each character believes she is young and behaves stereotypically like a preteen/teenage girl - their thoughts and behaviour that are revealed through focalisation and the narrators' descriptions of the characters' actions are reflective of the discourses of girlhood that each character has internalised. These discourses - that involve rather conventional notions about girlhood - are only deconstructed later when each girl regains her memory and becomes more aware about her past and present subjectivity. 


\section{Embodied memories: ways of doing young femininities}

The transformations of Sally and Vierran are similar in that at the beginning the characters and readers are unaware that a time slip has occurred: the characters are portrayed as young girls of thirteen (Sally) and twelve (Vierran/Ann). Sally is an invisible ghost drifting around her childhood surroundings. She has lost most of her memories but knows that there has been an accident and she has to find out what has happened. Sally's age-shifting is based on her experience of her spiritbody; her material body has not become invisible or younger but is lying mutilated in a hospital in the future. Vierran's transformation is somewhat different: placed in a distorted time- and spacefield created by a machine called the Bannus, Vierran believes she is a pre-teen girl called Ann. The Bannus has been programmed to test alternative courses of action with a certain group of people: in the Bannus field, events occur in a non-chronological order and Ann's task is to discover what is happening both in the virtual time and in the real time outside the game. It is unclear whether Vierran's material body has transformed or whether it is only the perception of her body that is manipulated; in terms of her experience of her body, this is insignificant. Ann has also lost her memory and spends part of her time in bed due to an illness but, unlike Sally, Ann is not aware of her memory loss but believes that her virtual identity is all that there is.

To solve the mysteries and escape confusion, each girl needs to regain her memory. Despite the disrupting time-shifts in the narratives, there exists a 'true', that is, a verifiable and chronological version of each girl's history. About halfway through The Time of the Ghost it is revealed that in the present time the 20-year-old Sally is lying in a hospital bed after her boyfriend threw her out of a moving car and she has been spirit-travelling in her past. For Sally, the chronological version of her history is located in the real past that she observes. A similar moment of revelation occurs in Hexwood when Vierran listens to her own voice on tape and regains her memory and thus her 21year-old identity. Her true narrative is based on a chronological sequence of events taking place in the real time outside the game. Thus, Vierran does not return to witness the past as it 'really' happened, but has to discern that the reality around her is produced by the computer, while the people in the game are real but in disguise.

Because both girls are unaware of their true age and focalisers of events, the time slips enable the representation of their experiences as pre-teen and teenage girls. Significantly, not all of their memories are erased. In fact, in terms of personality features both girls have a clear idea of who they are, as revealed through the narrative representation of their speech and thought. Moreover, if one accepts Braidotti's and Butler's theses that gender is 'tattooed on bodies' and habitually performed, it is possible to interpret each character's unconscious actions (as described by the external narrator) as based on their habitual memory that is not deleted during the time slips; the characters' behaviour is indicative of internalised discourses of girlhood. The characters habitually follow the internalised regulations guiding the suitable behaviour for girls - this is evident in each girls' reactions to non-normative behaviour. The representation of the girls before they realise their true age reflects discourses of conventional femininity: Sally is a 'nice girl' while Vierran is represented as a typical contemporary romance heroine ${ }^{4}$. In each case the return to girlhood means a 
limitation to agency, which is metaphorically represented through their illnesses that partly restrict their detective work. However, negative aspects conventionally associated with young femininities - lack of confidence, naivety, blind obedience, sense of embarrassment - are criticised in the texts through the use of structural irony.

In The Time of the Ghost, the narrative contrasts Sally's memories with the authentic past. During her spirit-travelling, Sally is forced to realise the sharp difference between her overly positive recollection of her childhood and the scenes of violence and parental neglect that she observes as an invisible witness. Sally's self-image as a nice girl is also challenged. The ghost's view of herself clashes with her sisters' view of her as overly tidy, pretentious, nagging and hysterical - in fact, a rather negative version of girlhood. While Sally does not accept her sisters' view of herself, the narration enforces the sisters' description:

I'm not like that! I'm not hysterical, and I don't go on about my career. I'm not like Imogen. They're just seeing their own faults in me! And I don't grumble and criticise. I'm ever so meek and lowly really - sort of gentle and dazed and puzzled about life. It's just that I've got standards.

(Jones 1981, pp.31-32, italics original)

The direct representation of Sally's thoughts reveals her behaviour without any explicit commentary by the narrator. Sally's emotional reaction here as in other, similar passages makes her seem hysterical (not a strange reaction to one's own invisibility and traumatic experiences). Sally's inability to register this is part of the structural irony that is an effective narrative device to reveal a character's nature; here it also functions as a way to expose and question the nice-girl discourse, which can be seen implied in the use of the word 'standards'. For Sally, her 'standards' refer to the ideal behaviour of a dutiful daughter: she is tidy, obedient, views her parents as perfect and regards herself as less peculiar and better behaved than her sisters. It is, however, made clear in the narrative that Sally is unaware of the negative consequences that applying her standards can lead to: her blind obedience and naïve belief in authorities make her an easy target for exploitation.

Indeed, Sally is portrayed as overly obedient. The ghost's conventional young feminine subjectivity is reflected in her reactions to any kind of norm-breaking as embarrassing. In the first chapter alone, the ghost feels 'foolish' climbing a fence and is 'glad no one was there to see her' (p.9), has 'a very strong sense of guilt' in the garden where she 'ought not to be' (p.9), is 'very much ashamed of her embarrassing mistake' of walking into a boys-only class (p.12), after walking into another 'forbidden' place she stands 'guiltily' in front of her mother who cannot see her (p.13) and a moment later she is embarrassed because she has witnessed her mother being embarrassed (p.14). These are represented as habitual reactions; Sally does not consciously ponder her continuous sense of shame. The ghost is not free even when invisible - she has internalised the normative discourse of an obedient girl and behaves as if she has a visible body. Her sense of embarrassment even extends to her artistic talent, upon which adult Sally's agency will be based. When the ghost sees a painting she recognises as her own, she reacts negatively: 'It was awful. It embarrassed her, it was so bad' (p.35). The chronic embarrassment 
characterises Sally's experience of being a girl who suffers from self-doubt and lack of self-confidence. These experiences are reflective of Sally's memories that have not been erased by the time shift. While it seems plausible that Sally has clung to the identity position of a nice girl because it has allowed her a positive view of herself in a situation where she has been neglected and exploited by others, the text clearly suggests that she should become aware of the negative aspects of this identity position and shed her old ways of doing gender. Because of the structural irony, readers are critical of the nice girl before Sally is; Sally only gets a clearer view of herself after she fully regains her memory.

The 12-year-old Ann is significantly different from the neurotic Sally. Ann reflects a more positive romance discourse of feisty heroines as a clever and adventurous girl who inspects the events taking place in the woods near her home. Ironically, to a certain extent Ann must be represented in stereotypical terms for readers to accept that she is twelve - playing with readers' expectations is a central part of Jones's narrative game. At the beginning - unlike in Sally's case - there is nothing mysterious about the girl Ann's identity: she believes she inhabits a pre-teen body and her girl identity is supported by other characters who view her as a child. The pre-teen Ann likes to pretend that she is older than she actually is (Jones 2000, p.261) and is worried about her fingernails and nice anorak even when while climbing into a tree to escape a potential killer (p.44). Ann's virtual parents treat her as a child and restrict her agency, for instance, by forcing her to stay inside even after she has recovered from her flu. Ann views this as utterly frustrating: 'I'm an active adolescent, not a bedridden invalid! I'm climbing the walls here!' (p.32, italics in original). Although Ann challenges her parents, she is anxious about rule-breaking: she worries about getting back home in time for lunch (p.55) and later, her mother's warnings continue to ring inside her head. Ann is habitually behaving according to a pre-teen femininity and, due to her stereotypical qualities, readers are fooled to believe in her young identity.

Like Sally, Ann is satirised by the narrator who describes her in awkward situations, thus highlighting the supposedly more ridiculous aspects of young femininity. Ann also thinks that behaviour that deviates from the norms is embarrassing if other people see what she is doing, and the incidents that Ann thinks are humiliating seem to reflect her supposed pre-teen identity. Ann is, for instance, 'acutely embarrassed' when a man shows her his wallet in the middle of the street and she sees that people are staring (p.95). Because Ann has previously witnessed much stranger incidents, it seems that her main worry here is that she is the object of other people's evaluating gaze. Since embarrassment is usually understood as an involuntary reaction, it reveals Ann's unconscious understanding of norms. In another passage, after she has climbed into a tree to escape a threatening-looking man, Ann finds herself in an embarrassing situation:

He looked up at Ann and croaked out a remark at her.

She recoiled against the tree trunk. Oh my God! He knew I was there all along! And now she was the indecent one. Comes of climbing trees in a tight skirt. The skirt was rolled up round her waist. He must be looking straight up at her pants. And her long, helpless legs dangling down on either side of the branch.

(Jones 2000, p.45) 
The 'indecent' figure sitting in the tree in a tight miniskirt trying to hide from a man is a humorous image of a feminine girl - or a damsel in distress who has chosen to wear a tight skirt even during her outdoor activities. Ann is represented as silly and her feminine outfit as unsuitable for adventures; she is not in control of the situation and her way of doing femininity is ridiculed. Elsewhere Vierran/Ann is described as clumsy and not particularly beautiful, and while her attempts to do conventional femininity in a miniskirt are satirised, it is suggested that her greatest asset is her cleverness. As the narrative unfolds, Ann moves further away from the girl attempting to do femininity by wearing nice clothes and becomes more critical as she begins to resemble her adult self - as Mendlesohn (2005, p.76) suggests, '[t]he more self-conscious Ann is, the closer she is to her own reality as Vierran'. For Ann, it is better to use her brains rather than aspire for a conventionally feminine appearance and the more Ann uses her brains, the more aware she becomes of her adult subjectivity.

In her discussion of Hexwood, Kaplan (2010) argues that the novel 'continually emphasises the difference between Ann the child and Vierran the young woman' (p.199) but I would maintain that this is partly because, at the beginning, readers view Ann and Vierran as two separate characters. Moreover, it is crucially important that the similarities of the two are described to build continuity between Vierran's differently aged selves. Kaplan (p.200) suggests that Vierran gains her selfknowledge 'by recognizing that her younger self is a fiction', and while this is true to a certain extent - Vierran is indeed not the 12-year-old Ann Stavely living on Earth - I would argue quite the opposite: Vierran's younger self is not fiction but reflects her own experiences of girlhood, including those behaviours that are later criticised. Vierran's identity and self-knowledge are based on the fact that she is now more conscious of her earlier identities that are not illusionary but based on her embodied memories. This is suggested in the novel when Vierran finds Ann similar to her pre-teen self when comparing them (Jones 2000, p.262). Also, in The Time of the Ghost, it is indicated that Sally's girlhood experiences are not completely based on an imagined identity because her behaviour as a ghost is aligned with her sisters' perception of her real past self. In terms of characterisation, then, the texts suggest that the girl identities are not illusionary but indeed based on memories of embodied girlhood - otherwise it would make no sense for the characters to compare their adult identities to their former selves when they regain their memory and contemplate their recent adventures as 'girls'. The continuity between the girls and the young adult women is provided at the moment the time games are revealed - regaining memory is necessary for each girl to know her personal identity and to become an agentive subject.

\section{Moments of coming-of-age: regaining identity and agency}

Initially, the time slips in the novels raise questions about the role of memory in subjectivity: the personal identity narratives are disrupted and the sense of embodiment is played with. However, the reconstruction of the real course of events in the narratives solves these problems by introducing causality, the links between the girls' past and present subjectivities and between their earlier choices and the consequences of those choices. Furthermore, when the characters realise their true age, they also acquire a judgmental perspective in relation to their earlier behaviour as girls and thus discourses of girlhood are criticised. 
When Sally wakes up in the hospital, the continuity between her younger and older selves is provided both by her own narrative memory that summarises her past actions, as well as her continuing embarrassment because she is 'ashamed to ask' the nurses about her identity since '[i]t seemed so silly not to know' (Jones 1981, p.99). Her memories show that the girl with 'standards' has developed into a conventionally feminine young adult woman who is indeterminate, docile and dependent on men. When her traumatic memories resurface, Sally realises that her past subjectivity has been constructed from other people's perceptions and wishes. As Ruth Waterhouse (1991, p.139) observes in her analysis of the narrative point of view in The Time of the Ghost, the older Sally's perspective at the hospital is a more judgmental one: it involves both a more comprehensive notion of the course of events and a moral stance towards her past actions. The older Sally's view of her past is grim: the seven years between the past and the present have been 'a time of fruitless mistakes' dominated by her father and her boyfriend between whom 'she had scarcely been a person' (Jones 1981, pp.112-113). Sally's invisibility and her broken body lying in the hospital bed are parts of the extended metaphor for the lack of agency and sense of self. At the end, after discovering her narrative Sally is able to change because she takes personal responsibility for her earlier 'wrong turn - a very wrong one' as a choice of clinging 'to something which was no good to [her]' that is, to her dominating boyfriend and her own submissive role. After understanding this she can do what she has always wanted: 'to paint, to paint well, to paint better and better' (pp.190191). The agency that Sally claims indicates a passage from youth to adulthood: it results from her identity as an artist, but is also based on the knowledge that her earlier identity position reflecting the 'nice girl' discourse cannot be viewed nostalgically but must be recognised as harmful and left behind. Her earlier identity based on negative aspects of conventional femininity is undone. The fact that Sally has yet to physically recover from the accident can also be interpreted as a further promise of change - to heal her body, she may have to learn again how to move, providing an opportunity to adopt new ways of behaving.

Hexwood involves a similar sobering moment after Vierran regains her memory. The 21-year-old Vierran immediately dismisses Ann's typical pre-teen behaviours by calling her a 'little idiot' (Jones 2000, p.262). In the same passage it becomes obvious that, in Vierran's view, to behave like a pre-teen girl when one is twenty-one is embarrassing: when she remembers herself in the tree, her face flushes hot and she hopes that 'Mordion had seen her only as the girl of twelve she had thought she was then' (p.262). As Kaplan (2010, p.200) writes, 'the story's climax includes overwhelming scorn ... for the behaviour of twelveyear-olds'. Kaplan views this as problematic in relation to the assumed age of the target audience, and I agree: in Vierran's view, girlhood as a period in a woman's life is negatively portrayed, it is something that one is glad to leave behind. Yet, the pre-teen Ann has not been represented as such an awful person as Vierran sees her, in fact, readers might be more sympathetic towards Vierran when they learn that she is the one formerly introduced as Ann - a brave, clever young woman.

It is clearly suggested that the older Vierran is the same as the earlier Ann in the game - the active and brave romance heroine - because the game cannot make a person 'do things which it is not in their natures to do' (pp.86-87). While a person's 'nature' seems to signal an essential identity, the word also indicates that the people and their subjectivities inside the game are not mere fictions. In 
the game, the setting and appearances are illusionary but the people in the game can - if they become conscious of the rules - act purposefully; whatever goes on inside the game may be based on disguised identities but those identities are no less real than the participants' identities outside the game. The continuity between Ann and Vierran is enforced in the representation of Vierran before the game as a brave, intelligent young woman who participates in a resistance movement against the Reigners, the rulers of the universe. However, the mature Vierran, the Vierran before the game, and Ann are not all exactly the same. When she remembers her real-time history, the mature Vierran dismisses not only the pre-teen Ann's behaviour but also her own more recent actions as the rebellious young woman, 'the Vierran of ten days ago', or the 'high-class sheltered little deb' (pp.261-262) as dangerous, irresponsible and naïve. Vierran thus rejects the negative aspects of her young feminine identity, naivety and irresponsibility and, by becoming critical of her own subjectivity, enters adulthood. As a reward, Vierran is made into one of the Reigners - her new role is based both on her identity narrative and on her unique, innate Reigner qualities.

From the perspective of the whole narrative, the girls' age-shifting is empowering because the time slips allow (or force) the protagonists to realise who they really are and leave behind their misconceived selfimages. When the girls return to their adult bodies their old ways of doing femininity become deconstructed as they become aware of their earlier behaviour and want to change. In this sense the fantastic time slips and transformations replace the psychological process of reconstructing a self through memory, or even through therapy where one re-experiences the past (cf. Brison 1999). In The Time of the Ghost the (re)construction of a coherent subjectivity at the close can be seen as necessary in terms of trauma - Sally is recovering from a disastrous relationship and a severe accident. However, if adulthood is understood as an identity connected with agency and responsibility, Sally's new-found identity may also be interpreted as a result of a maturation process. A similar process takes place for Vierran. Regaining their subjectivity after the time shifts is a liberating experience. The mysteries are solved, personal identity narratives are reconstructed and each girl finds their 'true' calling. This seems to echo discourses of liberal feminism that celebrate empowerment, individual agency and finding of one's unique identity. The mystery narrative structure in the novels supports the liberal-feminist discourse at the close - conventionally there must be a solid, logical solution to the mystery and Jones's novels follow this rule. In these novels the solution to the mysteries involves both the reconstructed identity narratives and the realisation of the girls' unique talents.

Nevertheless, an agentive subjectivity is also necessary from the perspective of poststructuralist feminist theory. The invisible Sally drifting forever in her past or Ann trapped in the non-chronological game might seem to be perfect examples of fluid, postmodern subjects, but from a feminist perspective these are not particularly optimistic ways to represent female subjective agency. As Braidotti (2005, p.62) writes, non-unitary, nomadic subjects inhabit 'a time that is the active tense of continuous "becoming" and thus their identities will never be fixed to one thing; however, Braidotti also maintains that 'one cannot deconstruct a subjectivity one has never been fully granted control over' (p.82). A person who does not know who she is and has no agency is not a subject. Thus, the ghostly Sally and the amnesic Ann need a personal identity narrative and a sense of their own material body to become agentive subjects - life narratives and bodies are not fixed, but constantly in the process of becoming. 
Yet, while agency is necessary, the portrayal of the connection between agency and personal responsibility in the novels is somewhat problematic. Although both time-shifting girls are initially almost completely robbed of agency, they have not been without agency in their real young adult lives. They experience the time slips, in the first place, as a result of their own actions: Sally is initially responsible for her accident by offering herself as a sacrifice to an ancient goddess and by entering into a relationship with a violent young man. Vierran has been transported from her home planet to Earth and into the Bannus field by a Reigner who has considered her rebelliousness threatening. The pattern of maturation through guilt and self-accusation is somewhat disturbing because it reflects a victim's discourse, taking responsibility for acts of violence, involving the idea that a victim provokes the perpetrator's violent action. Violent behaviour is certainly not endorsed in Jones's novels but the perpetrator's responsibility is backgrounded because Sally's and Vierran's personal responsibility for their past behaviours is represented as a necessary aspect of maturation. Ironically, this responsibility is also the aspect that provides the real twist in both narratives. While the girls are initially responsible for getting involved in the time games because of their 'mistakes' or 'wrong choices', these same actions are empowering because they initiate their own maturation process. Had they not experienced the time slips and age-shifting, they would not have reached the self-awareness that they need to develop a fully agentive subjectivity. Thus, agency in these novels cannot be understood merely in a positive sense, which adds complexity to the representation of female subjectivity in the texts.

Furthermore, individual agency is challenged in these novels by emphasising intersubjectivity. Both Sally's and Vierran's stories demonstrate that their subjectivity is a socially mediated process: as amnesiacs they are crucially dependent on, in Cavarero's terms, the 'necessary others' to fill in their narratives and thus to participate in the interpersonal construction of their subjectivity. Interdependency can here be seen as a positive factor rather than as a proof of their lack of independence, skills or potential. Sally's necessary others are her sisters, who share their own views of the past with Sally to help her complete her own story. Similarly, Vierran relies on the four voices in her head to fill in her narrative and, at the end, joins the actual people to whom the voices belong to form the new group of Reigners. Intersubjectivity plays a remarkable part in each girl's search for her identity; the novels display that the past, as well as subjectivities, are interpersonally constructed in the present.

\section{Conclusion}

In The Time of the Ghost and in Hexwood, age-shifting functions as a narrative device that initially deconstructs the embodied and narrative aspects of the girl protagonists' subjectivities and causes readers to experience a level of uncertainty at the beginning of these narratives. Both texts critically address the role of memories in identity formation and challenge certain ways of doing gender. Through the use of structural irony, certain aspects of the characters' young femininities are satirised and discourses of conventional femininity are deconstructed after the girls leave their mysterious, disturbing states as amnesiacs and become aware of their past and present selves. In Hexwood the complex narrative structure highlights how sense of agency is tied to time, causality and memory - not only for Vierran, but everyone else in the game. However, in The Time of the Ghost the lack of agency is more clearly associated with negative aspects of conventional femininity. 
While the time slips and age-shifting temporarily disrupt the natural aging process, in each novel there is one true narrative that results from putting the pieces together; the return to young adulthood at the end emphasises the desirability of adult subjectivities in opposition to the irresponsible, naive girl subjectivities. The mystery narrative structure emphasises the new identities at the ending as logical solutions to the uncertainty experienced (by both protagonists and readers) earlier in the narrative. This is somewhat problematic, since girlhood is associated with naïvety, irresponsibility and embarrassment, and the passage to adulthood and agentive subjectivity is reached through feelings of guilt and self-accusation. Nevertheless, from a feminist perspective it is desirable that the girls' coming-of-age is represented as an empowering experience of acquiring an agentive adult subjectivity and leaving behind misconceived self-images based on conventional discourses of girlhood. The characters' adult identities seem to reflect a liberal feminist project of finding one's identity - yet, this does not necessarily imply that their identities become fixed. The time slips and age-shifting have deconstructed each character's earlier sense of self and have demonstrated that transformation is possible if one becomes aware of both one's past and one's present ways of performing identities. Thus, an identity based on narrative, or a nomadic subjectivity is always open to change.

\section{Endnotes}

${ }^{1}$ Magic age-shifting does not always contribute to identity construction, as in cases where ageshifters do not recollect their experiences of their transformations afterwards. In Edith Nesbit's The Enchanted Castle (1907) a wishing ring turns a boy into an elderly gentleman who no longer recognises his siblings, and in Penelope Farmer's The Castle of Bone (1972) a teenage boy accidentally falls into a magic cupboard that first turns him into a toddler and then a newborn baby who does not remember his earlier selves. In these examples the characters have no memory of their transformation after being turned back into their usual selves. The continuity needed to maintain a sense of self is lost and the old and young selves become different persons.

${ }^{2}$ An example of this is F. Anstey's Vice Versa (1881) where a father and a son swap bodies. The father refuses to act his new age and attempts to maintain his adult authority, which turns out to be impossible: other characters interpret his behaviour as strange, comic or transgressive for a child.

${ }^{3}$ While age-shifting in Jones's stories is magically induced, other contemporary novels, such as Margaret Haddix's Turnabout (2000) and Marilyn Kaye's Happy Birthday, Dear Amy (2001) introduce 'scientifically' explained abrupt changes in age.

${ }^{4}$ I have elsewhere (Lehtonen 2008) discussed Sally's invisibility as a metaphor for powerlessness conventionally associated with femininity; here the focus is on her age-shifting and the juxtaposition of her young and old identities. 


\section{References}

Anstey, F. (1981/1881) Vice Versa. Harmondsworth, Puffin.

Bal, M. (1999) 'Introduction', in M. Bal, J. Crewe \& L. Spitzer (eds) Acts of Memory: Cultural Recall in the Present. Hanover, University Press of New England, pp.vii-xvii.

Braidotti, R. (2005) Metamorphoses: Towards a Materialist Theory of Becoming. Cambridge, Polity Press.

Brison, S. J. (1999) 'Trauma narratives and the remaking of the self', in M. Bal, J. Crewe \& L. Spitzer (eds) Acts of Memory: Cultural Recall in the Present. Hanover, University Press of New England, pp.39-54.

Butler, C. (2006) Four British Fantasists: Place and Culture in the Children's Fantasies of Penelope Lively, Alan Garner, Diana Wynne Jones, and Susan Cooper. Lanham, The Scarecrow Press.

Butler, J. (1996) 'Gender as performance', in P. Osborne (ed.) A Critical Sense: Interviews with Intellectuals. London, Routledge, pp.109-125.

Butler, J. (1999) Gender Trouble: Feminism and the Subversion of Identity. New York, Routledge.

Cavarero, A. (2000) Relating Narratives: Storytelling and selfhood. London, Routledge.

Cosslett, T. (2002) "'History from below": Time-slip narratives and national identity', The Lion and the Unicorn, 26, 2, 243-253.

Cruikshank, M. (2003) Learning To Be Old: Gender, Culture, and Aging. Lanham, Rowman \& Littlefield.

Farmer, P. (1992/1972) A Castle of Bone. London, The Bodley Head.

Foucault, M. (1979) Discipline and Punish: The Birth of the Prison. London, Vintage Books.

Haddix, M. (2000) Turnabout. New York, Simon \& Schuster.

Hall, L. (2001) "“Time no longer" - history, enchantment and the classic time-slip story', in F. M. Collins and J. Graham (eds) Historical Fiction for Children: Capturing the Past. London, David Fulton, pp.43-53.

Jones, D. W. (1981) The Time of the Ghost. London, Macmillan Children's Books.

Jones, D. W. (1984) Archer's Goon. London, Methuen.

Jones, D. W. (1985) Fire and Hemlock. London, Methuen.

Jones, D. W. (2001/1986) Howl's Moving Castle. New York, HarperCollins.

Jones, D. W. (2000/1993) Hexwood. London, HarperCollins.

Kaplan, D. (2010) 'Disrupted expectations: young/old protagonists in Diana Wynne Jones's novels', Journal of the Fantastic in the Arts, 21, 2, 197-209.

Kaye, M. (2001) Happy Birthday, Dear Amy (Replica 16). New York, Bantam Books.

Lehtonen, S. (2008) 'Invisible girls: discourses of femininity and power in children's fantasy', International Research in Children's Literature, 1, 2, 213-226.

Mendlesohn, F. (2005) Diana Wynne Jones: Children's Literature and the Fantastic Tradition. London, Routledge.

Nesbit, E. (1956/1907) The Enchanted Castle. London, Ernest Benn Limited.

Rumbold, M. (1997) 'Taking the subject further', Papers, 7, 2, 16-28.

Waterhouse, R. (1991) 'Time for a ghostly point of view', Papers, 2, 3, 135-142.

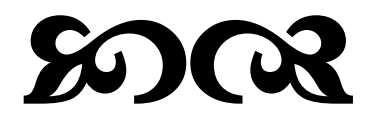




\section{Biographical Note}

Dr Sanna Lehtonen is a Postdoctoral Researcher in the Department of Culture Studies, Tilburg University in a project called 'Transformations of the Public Space' where she examines the reception of adult and children's literature in social media. She completed her joint $\mathrm{PhD}$ in English language and literature at the University of Jyväskylä (Finland) and Macquarie University (Australia) in 2010. She has published articles on gender, social class and ethnicity in children's literature and is currently writing a book on girlhood, invisibility and age-shifting in children's fantasy (forthcoming from McFarland). 